\title{
Moderate Hyperthermia Induces Apoptosis in Metaphase-Arrested Cells But Not in Interphase Hela Cells
}

\author{
James R. Paulson 1* ${ }^{*}$, Agnes Kecskeméti Kresch ${ }^{1,2}$, Peter W. Mesner ${ }^{3}$ \\ ${ }^{1}$ Department of Chemistry, University of Wisconsin, Oshkosh, WI, USA \\ ${ }^{2}$ Prevea St. Mary's Health Center, Green Bay, WI, USA \\ ${ }^{3}$ Department of Biological Sciences, University of Wisconsin, Whitewater, WI, USA \\ Email: "paulson@uwosh.edu
}

Received 19 May 2016; accepted 24 June 2016; published 27 June 2016

Copyright $(2016$ by authors and Scientific Research Publishing Inc.

This work is licensed under the Creative Commons Attribution International License (CC BY). http://creativecommons.org/licenses/by/4.0/

(c) (i) Open Access

\begin{abstract}
Metaphase-arrest agents and hyperthermia are both known to be capable of inducing apoptosis, and they have been used, separately, in cancer treatments. Here, we have examined whether the two treatments together may have a synergistic effect. We find that when H-HeLa cells are arrested in metaphase with spindle poisons (nocodazole or paclitaxel) and then subjected to mild heat treatment $\left(41.5^{\circ} \mathrm{C}\right)$, they exhibit morphological changes typical of apoptosis within three hours. Moreover, those changes are blocked by the pan-caspase inhibitor zVAD-fmk, indicating apoptosis, and activated Procaspase 3 is detected by immunoblotting and by staining with the fluorescein-labelled caspase inhibitor FAM-VAD-fmk. Interphase cells treated in the same way do not undergo apoptosis, even with spindle poisons present. Induction of apoptosis is more rapid when the cells have been arrested longer in metaphase, suggesting that accumulation or depletion of some cellular component(s) during metaphase-arrest may make them more susceptible to hyperthermia. Further work is in progress to test whether other cell lines exhibit the same behavior and to learn more about the mechanism. The phenomenon is of interest because it may provide clues to how hyperthermia induces cell death and may yield novel therapeutic approaches to block or stimulate apoptosis.
\end{abstract}

\section{Keywords}

Apoptosis, Caspase, Heat Treatment, H-Hela, Hyperthermia, Metaphase-Arrest, Mitosis, Nocodazole, Paclitaxel, zVAD-fmk

\footnotetext{
${ }^{*}$ Corresponding author.
}

How to cite this paper: Paulson, J.R., Kresch, A.K. and Mesner, P.W. (2016) Moderate Hyperthermia Induces Apoptosis in Metaphase-Arrested Cells But Not in Interphase Hela Cells. Advances in Biological Chemistry, 6, 126-139. 


\section{Introduction}

Apoptosis is a process of programmed cell death by which unneeded or unwanted cells are eliminated from the body without inflammation. It plays an important role in embryological development, in the body's defense against disease, and in surveillance for cells that may become cancerous. It is characterized by major biochemical and morphological changes within the cell which are initiated either by an extrinsic pathway, involving specific cell surface receptors, or by an intrinsic pathway that may be triggered by stress to the cell [1] [2]. In either case, specific proteases called caspases are activated which carry out the actual "execution" of the cell [3]-[5]. The action of caspases produces the distinguishing features of apoptosis including changes in cell shape, blebbing of the plasma membrane, fragmentation of nuclear DNA, hypercondensation and fragmentation of the chromatin, and proteolyic cleavage of various proteins [3]-[6].

Apoptosis is also involved in the mechanism of cell killing in cancer chemotherapy and radiotherapy [1] [7]-[11]. In particular, it plays a role in therapies using hyperthermia and spindle poisons. A number of studies have shown that mild hyperthermia (heat treatment) is useful in treating tumors and that it works by inducing apoptosis (e.g., [12]-[15]). Its cytotoxic effects can be amplified when used in conjunction with radiotherapy or chemotherapy [16]. Spindle poisons work by either disassembling microtubules (e.g., nocodazole and vinblastine) or stabilizing them (e.g., paclitaxel). In either case, the function of the mitotic spindle is disrupted, leading to arrest of the cells in metaphase of mitosis. (Properly speaking, the cells are arrested in prometaphase, but for simplicity we follow common practice and refer to them as metaphase-arrested.) These reagents are also used in cancer chemotherapy and are capable of inducing apoptosis (e.g., [17] [18]).

In the work reported here, we have examined for the first time the effects of mild hyperthermia on metaphase-arrested cells. The initial impetus for this project was the observation, in an earlier study [19], that metaphase-arrested HeLa cells subjected to mild heat treatment appear to undergo apoptosis. It was also motivated by the idea that the combination of spindle poisons and hyperthermia might induce apoptosis more efficiently than either one alone, and that this might lead to a more effective cancer treatment. Using a HeLa strain called H-HeLa [20], we show that mild hyperthermia indeed induces apoptosis in metaphase-arrested cells but not in interphase cells.

\section{Materials and Methods}

\subsection{Chemicals and Media}

zVAD-fmk was obtained from Calbiochem (La Jolla, CA), dissolved to $50 \mathrm{mM}$ in DMSO, and stored at $-20^{\circ} \mathrm{C}$. Propidium iodide and FAM-VAD-fmk (APO-LOGIX ${ }^{\mathrm{TM}}$ Carboxyfluorescein Caspase Detection Kit) were obtained from Cell Technologies, Inc., Minneapolis, MN, and were prepared and used as prescribed by the manufacturer. Tissue culture media and supplements were obtained from Invitrogen (GIBCO) or Sigma. All other reagents were obtained from Sigma unless otherwise noted.

\subsection{HeLa Cell Culture}

A strain of HeLa cells designated H-HeLa [20] was obtained from Prof. R. Rueckert at the University of Wisconsin-Madison. This strain is now available from the American Type Culture Collection (H1 HeLa, ATCC ${ }^{\circledR}$ CRL-1958' ${ }^{\mathrm{TM}}$ ) (H-HeLa is primarily known for its susceptibility to rhinoviruses and polioviruses, e.g., [21]). Unless otherwise noted, the cells were grown in Eagles minimal essential medium with Earles salts (MEM) supplemented with 100 i.u./mL penicillin, $100 \mu \mathrm{g} / \mathrm{mL}$ streptomycin, 5\% newborn calf serum (heat inactivated), nonessential amino acids, $2 \mathrm{mM}$ glutamine and $1 \mathrm{mM}$ sodium pyruvate. Stock cultures were maintained as spinner cultures $\left(2 \times 10^{5}-5 \times 10^{5}\right.$ cells $\left./ \mathrm{mL}\right)$ with 2 inch Teflon-coated stirring bars in $500 \mathrm{~mL}$ bottles at $37^{\circ} \mathrm{C}$ [22]. The cells produce enough $\mathrm{CO}_{2}$ to condition the medium and maintain the correct $\mathrm{pH}$, so the composition of the atmosphere does not need to be controlled (i.e., with $5 \% \mathrm{CO}_{2}$ ).

\subsection{Cell Synchronization and Metaphase Arrest}

For most experiments, suspension cultures were synchronized in S-phase by treatment with $2.5 \mathrm{mM}$ thymidine [23]. After 19 - 24 hours the cells were pelleted, washed with $0.9 \% \mathrm{NaCl}$ solution, resuspended in fresh medium, and further incubated at $37^{\circ} \mathrm{C}$ (or in some experiments at lower temperatures). In most cases, nocodazole was 
added to a final concentration of $0.25 \mu \mathrm{g} / \mathrm{mL}$ (from a stock solution $5 \mathrm{mg} / \mathrm{mL}$ in DMSO) 4 hours after removal of thymidine. In experiments involving metaphase arrest with paclitaxel, $0.25 \mu \mathrm{M}$ paclitaxel was added (from a stock solution $2 \mathrm{mM}$ in DMSO) instead of nocodazole. Cultures with viabilities of $90 \%$ - $95 \%$ and mitotic indices above $80 \%$ were routinely obtained at 16 - 20 hours after release from thymidine. For experiments to determine the extent of apoptosis as a function of the length of time the cells had spent in metaphase-arrest, HeLa cells were seeded into $75 \mathrm{~cm}^{2}$ (T75) tissue culture flasks at $5 \times 10^{6}$ cells per flask. After 24 hrs at $37^{\circ} \mathrm{C}$ (in a humidified, $5 \% \mathrm{CO}_{2}$ incubator), the medium and unattached cells were removed and fresh medium containing 0.25 $\mu \mathrm{g} / \mathrm{mL}$ nocodazole was added. After an additional $2 \mathrm{hrs}$ at $37^{\circ} \mathrm{C}$, flasks were shaken gently to selectively dislodge the weakly attached mitotic cells. Cells were pelleted and resuspended to a concentration of $3 \times 10^{5}-4 \times$ $10^{5}$ cells $/ \mathrm{mL}$ in fresh medium containing $0.25 \mu \mathrm{g} / \mathrm{mL}$ nocodazole. For the experiment to test the effects of various types and concentrations of serum, cells growing in monolayers in T75 flasks were treated for 16 hours with nocodazole and mitotic cells were obtained by gentle shake-off.

\subsection{Light Microscopy and Determination of Cell Viability}

For determination of the percentage of cells in mitosis, apoptosis and interphase, $200 \mu \mathrm{L}$ of water containing 20 $\mu \mathrm{g} / \mathrm{mL}$ Hoechst 33342 was added to $200 \mu \mathrm{L}$ of cell culture. After allowing $5 \mathrm{~min}$ at room temperature for hypotonic swelling, $40 \mu \mathrm{L}$ of fixative (3:1, methanol:acetic acid) was added [24]. Samples were viewed by epifluorescence using a Nikon Labophot microscope with a 40× objective. By this procedure, metaphase, interphase, and apoptotic cells can be easily distinguished. For each sample, at least 200 cells were counted and scored as metaphase, interphase, or apoptotic. In some experiments, unfixed cells were viewed by Hoffman modulation contrast to document cell morphology.

Cell viability was determined using Trypan Blue [25] or propidium iodide staining. In the latter case, cells from $1.2 \mathrm{~mL}$ of culture were gently pelleted and resuspended in $50 \mu \mathrm{L}$ of the same medium, and $5 \mu \mathrm{L}$ of propidium iodide solution $(0.25 \mu \mathrm{g} / \mathrm{mL}$ in saline) was added. Microscope slides were scanned on a raster and in each field the dead cells (propidium iodide-stained) were counted using epifluorescence and total cells were counted using phase contrast.

For FAM-VAD-fmk staining, the inhibitor (150× in dimethylsulfoxide) was diluted 5-fold with phosphatebuffered saline to obtain the working (30×) stain solution and $10 \mu \mathrm{L}$ of this working solution was mixed with $300 \mu \mathrm{L}$ of cell culture. After incubation in the dark for $1 \mathrm{hr}$, cells were washed once with diluted wash buffer (Cell Technology, Inc.), resuspended in wash buffer and viewed by epifluorescence. Fluorescent cells were scored as apoptotic; total cells were counted under phase contrast.

\subsection{Heat Treatment of Cell Cultures and Addition of zVAD-fmk}

For heat treatments, aliquots of cell cultures that had been arrested in metaphase were placed in water baths at the appropriate temperatures. Generally, heat treatment was carried out in small (25 or $50 \mathrm{~mL}$ ) Erlenmeyer flasks with rubber stoppers, using gentle agitation in a water-bath shaker. For experiments involving the caspase inhibitor zVAD-fmk, heat treatments were carried out in $1.5 \mathrm{~mL}$ microcentrifuge tubes with occasional gentle mixing to keep the cells in suspension. Measured amounts of the inhibitor were added to the tubes before adding cells. The atmosphere inside culture vessels was not controlled during the heat treatments, but this did not appear to affect the induction of apoptosis. The $\mathrm{pH}$ of each culture was monitored by noting the color (due to phenol red) of the medium. In some experiments neutral $\mathrm{pH}$ was maintained whereas in others it was not (particularly when the flask or tube was opened frequently for sampling), but this did not appear to make any difference in the percentage of apoptotic cells observed.

Cell concentrations in cultures were adjusted to approximately $2 \times 10^{5}$ cells/mL immediately before beginning heat treatments. Typically the cells were incubated at elevated temperatures for 3 - 5 hours. Samples were taken periodically and the percentages of metaphase, interphase and apoptotic cells determined as described above.

\subsection{SDS-Polyacrylamide Gel Electrophoresis and Western Blotting}

Cells were chilled, sedimented at $100 \times g$, washed once in $15 \mathrm{~mL}$ of ice cold PBS, and lysed on ice at a concentration of $1 \times 10^{7}$ cells/mL in cold RIPA Buffer (consisting of PBS with $1 \%$ NP-40, 0.5\% sodium deoxycholate, and $0.1 \%$ SDS) containing $100 \mathrm{mM}$ PMSF, $2 \mu \mathrm{g} / \mathrm{mL}$ Leupeptin, and $2 \mu \mathrm{g} / \mathrm{mL}$ Pepstatin A. Protease inhibitors 
were diluted immediately before use from $1000 \times$ stock solutions prepared in anhydrous alcohol. Lysates were cleared of insoluble debris by centrifugation in a microcentrifuge at $4^{\circ} \mathrm{C}$ for 10 minutes at full speed. Protein concentrations were determined using the Bradford assay reagent (BioRad), and the cleared lysates were stored in small aliquots at $-80^{\circ} \mathrm{C}$. For Western blotting, samples containing $50 \mu \mathrm{g}$ total protein were separated by SDS-polyacrylamide gel electrophoresis with $4 \%$ acrylamide in the stacking gel and $15 \%$ acrylamide in the separating gel. Separated proteins were electrophoretically transferred ( $100 \mathrm{~V}$ for 50 minutes) to Immobilon PVDF nylon membranes (Millipore) in transfer buffer (25 mM Tris, $192 \mathrm{mM}$ glycine, 20\% methanol and 0.02\% SDS). Following transfer, filters were stained in 0.1\% Fast Green FCF in 20\% methanol, 5\% acetic acid and molecular weight marker bands were marked. Filters were then destained in $20 \%$ methanol, $10 \%$ acetic acid, blocked overnight at room temperature in TS buffer $(10 \mathrm{mM}$ Tris, $150 \mathrm{mM} \mathrm{NaCl})$ containing $5 \%$ powdered milk, and probed at room temperature $1 \mathrm{hr}$ to overnight with primary antibodies diluted 1:500 in blocking buffer containing $0.1 \%$ sodium azide as a preservative. The rabbit-derived primary antibodies used were anti-human Caspase 3 (Santa Cruz Biotechnology) and anti-human actin (Sigma). All primary antibodies were detected by blotting for $1 \mathrm{hr}$ at room temperature with goat-anti-rabbit IgG-HRP (Santa Cruz) diluted 1:1000 in PBS containing 3\% milk. Bound secondary antibodies were visualized by exposure of Kodak X-Omat AR X-ray film following enhanced chemiluminescent staining as previously described [26].

\section{Results}

\subsection{Mild Hyperthermia Induces Cell Death in Metaphase-Arrested Hela Cells But Not in Interphase Cells}

In order to observe the effects of hyperthermia, metaphase-arrested cultures of H-HeLa cells were either left at $37.0^{\circ} \mathrm{C}$ or treated at $41.5^{\circ} \mathrm{C}$ for three hours, and samples from control (not heat-treated) and heat-treated cultures were viewed by epifluorescence microscopy following staining with Hoechst 33342 (Figure 1). Control cultures left at $37.0^{\circ} \mathrm{C}$ retained the usual appearance of metaphase-arrested cells (Figure 1(a)). However, cells subjected to hyperthermia exhibited morphological changes characteristic of apoptosis, such as blebbing of the plasma membrane, nuclear condensation, and nuclear fragmentation (Figure 1(b)).

During time courses of heat treatment (Figure 2), the rate of induction of apoptosis was monitored by periodically preparing samples for fluorescence microscopy and counting the number of mitotic, interphase, and apoptotic cells. Figure 2(a) shows that during heat treatment of a metaphase-arrested culture there is a steady decline

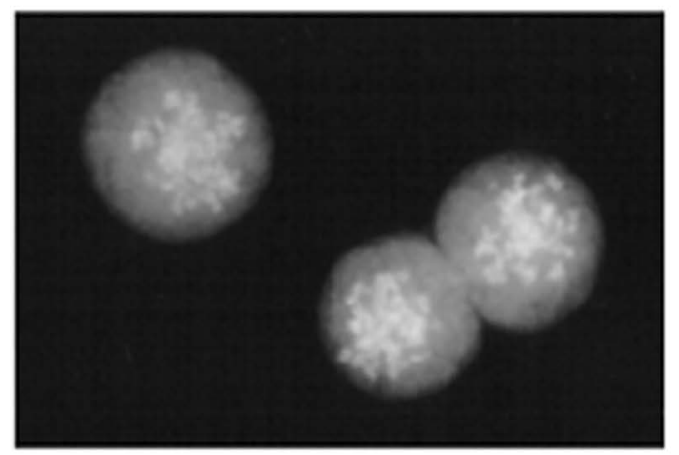

(a) Control

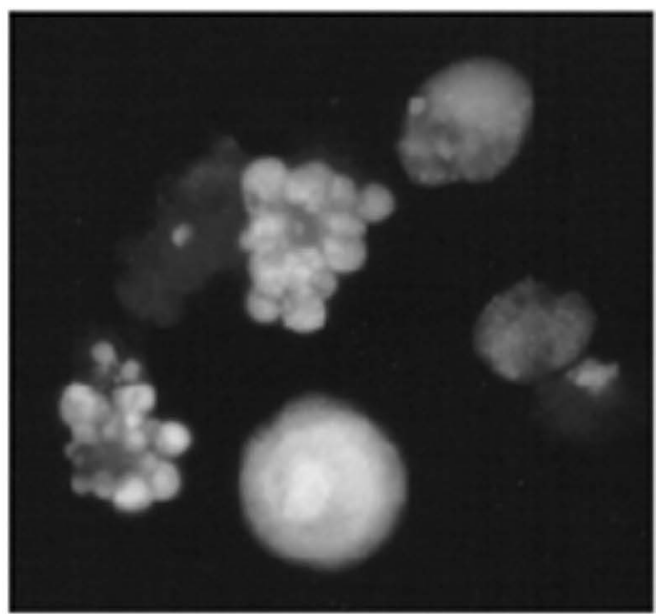

(b) Heat treated

Figure 1. Heat treatment of metaphase-arrested H-HeLa cells induces morphological changes typical of apoptosis. Cells growing in suspension at $37.0^{\circ} \mathrm{C}$ were synchronized in S-phase with thymidine, released, and arrested in metaphase with nocodazole (see Materials and Methods). Aliquots of the culture (mitotic index $85 \%$ ) were either left at $37.0^{\circ} \mathrm{C}$ or shifted to $41.5^{\circ} \mathrm{C}$. After $3 \mathrm{hrs}$ samples were stained with Hoechst 33342 and prepared for fluorescence microscopy. (a) Control. After the additional $3 \mathrm{hrs}$ at $37.0^{\circ} \mathrm{C}$, cells are still in metaphase arrest. (b) Heat treated. After $3 \mathrm{hrs}$ at $41.5^{\circ} \mathrm{C}$, most cells show morphological changes characteristic of apoptosis, including blebbing of the plasma membrane, nuclear condensation and nuclear fragmentation. One interphase cell can be seen (bottom center), but no mitotic cells are observed. 

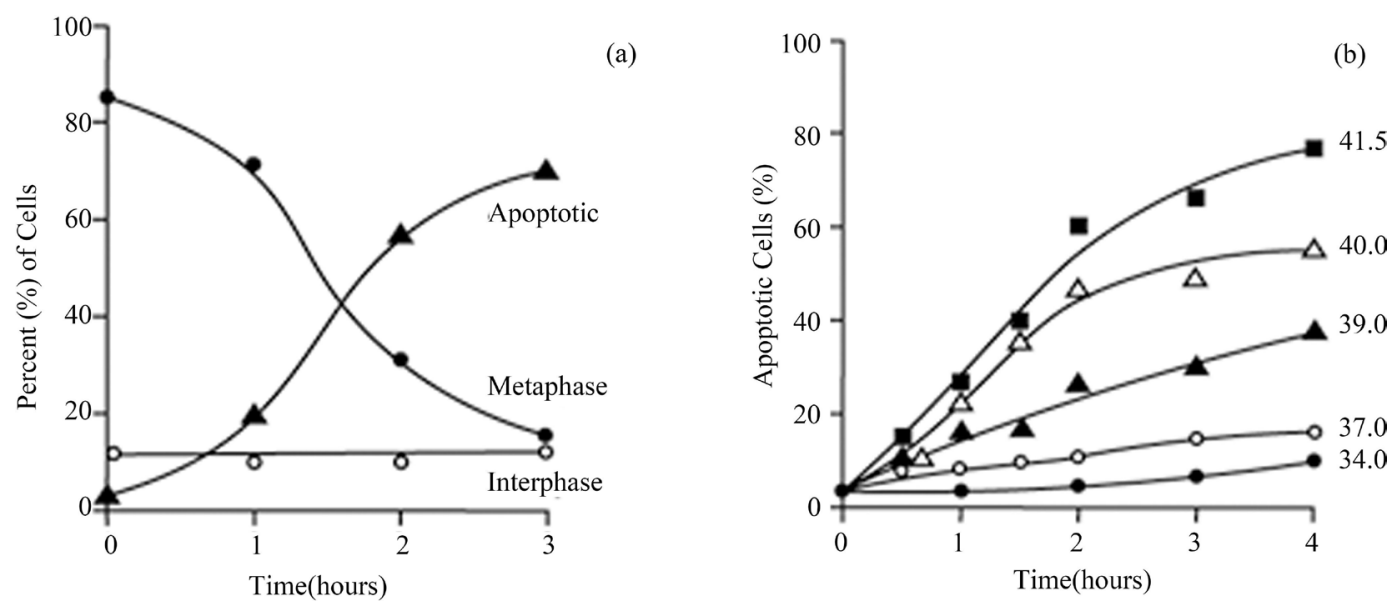

Figure 2. Time course and temperature dependence of induction of apoptosis during heat treatment of metaphase-arrested $\mathrm{H}-\mathrm{HeLa}$ cells. Cultures were arrested in metaphase at $37^{\circ} \mathrm{C}$ and shifted to the indicated temperatures. At various times, samples were prepared for fluorescence microscopy. Apoptotic cells were scored on the basis of cell and nuclear morphology (cf. Figure 1(b)). (a) Percentages of interphase $(\circ-\circ)$, metaphase $(\bullet-\bullet)$, and apoptotic cells $(\boldsymbol{\Delta}-\mathbf{\Delta})$ after shift of a culture (mitotic index $86 \%$ ) to $41.4^{\circ} \mathrm{C}$. (b) Percentages of apoptotic cells after shifting aliquots of a culture (mitotic index $91 \%$ ) to $34.0(\bullet-\bullet), 37.0(\circ-\circ), 39.0(\boldsymbol{\Delta}-\boldsymbol{\Delta}), 40.0(\Delta-\Delta)$ and $41.5^{\circ} \mathrm{C}(\boldsymbol{\bullet}-\mathbf{\square})$. Note that apoptosis is induced more rapidly at higher temperatures.

in the number of metaphases and a corresponding increase in the number of apoptotic cells, but the number of interphase cells stays roughly constant. Even in cases where the mitotic index was low and $40 \%-50 \%$ of the cells were still in interphase, the percentage of interphase cells remained constant throughout the heat treatment. This suggested that only metaphase-arrested cells were undergoing apoptosis.

The experiment shown in Figure 2(b) demonstrates that the rate and extent of induction of apoptosis is greater when the metaphase-arrested cells are treated at a higher temperature. For example, nearly $80 \%$ of cells were apoptotic after three hours of treatment at $41.5^{\circ} \mathrm{C}$, whereas only $38 \%$ were apoptotic after treatment for three hours at $39.0^{\circ} \mathrm{C}$.

To test the hypothesis that only metaphase cells, and not interphase cells, undergo apoptosis during heat treatment, metaphase-arrested and interphase (unsynchronized) cultures were directly compared. Figure 3(a) shows clearly that heat treatment does not induce apoptosis to a significant extent in interphase cells after 3 hrs at $41.5^{\circ} \mathrm{C}$, and the same is true at lower temperatures. However, nearly all metaphase-arrested cells have become apoptotic after $3 \mathrm{hrs}$ at $41.5^{\circ} \mathrm{C}$. Some apoptosis occurs in metaphase-arrested cells even at $37^{\circ} \mathrm{C}$.

The occurrence of cell death following heat treatment of metaphase-arrested HeLa cells (but not interphase cells) was confirmed by the use of propidium iodide, which stains the nuclei of dead (permeabilized) cells but does not stain intact, living cells. As indicated in Figure 3(b), an interphase culture treated at $41.5^{\circ} \mathrm{C}$ shows little or no increase in the number of dead cells over the course of $7 \mathrm{hrs}$. There is a small, gradual increase in the number of dead cells in a metaphase-arrested culture left at $37.0^{\circ} \mathrm{C}$. However, the number of dead cells rises dramatically in a metaphase-arrested culture treated at $41.5^{\circ} \mathrm{C}$. When assayed by propidium iodide staining (Figure 3(b)), cell death during treatment at $41.5^{\circ} \mathrm{C}$ lags about 2 hrs behind the morphological changes observed in Figure 1(b), Figure 2 and Figure 3(a).

The membrane "blebbing" characteristic of apoptotic cells can also be observed by Hoffman modulation contrast, which gives a "shadowed" image similar to that seen with differential interference contrast (DIC). Blebbing is seen with heat-treated metaphase-arrested cells (Figure 4(b)) but not with heat-treated interphase cells (Figure 4(d)).

\subsection{Further Evidence That the Observed Phenomenon Is Apoptosis}

As described above, metaphase-arrested HeLa cells treated with mild hyperthermia undergo cell death and show morphological changes typical of apoptosis (Figure 1). To check whether these morphological changes are truly a sign of apoptosis, we tested whether they could be prevented by adding the cell-permeable pan-caspase inhibitor zVAD-fmk [3] [27] [28] during the heat treatment. Figure 5(a) shows that indeed, the changes induced in 
metaphase-arrested cells by hyperthermia are blocked by zVAD-fmk. Figure 5(b) shows further that when metaphase-arrested cells are treated for $3 \mathrm{hrs}$ at $41.5^{\circ} \mathrm{C}$, the presence of $40 \mu \mathrm{M}$ zVAD-fmk reduces the percentage of cells with morphological changes typical of apoptosis by about 50\% while $350 \mu \mathrm{M}$ zVAD-fmk almost completely eliminates them. In an experiment analogous to that shown in Figure 3(b), zVAD-fmk also prevented the cell death observed by staining with propidium iodide (data not shown). These results confirm that the cell death and morphological changes we observe require caspases and are indeed the result of apoptosis.
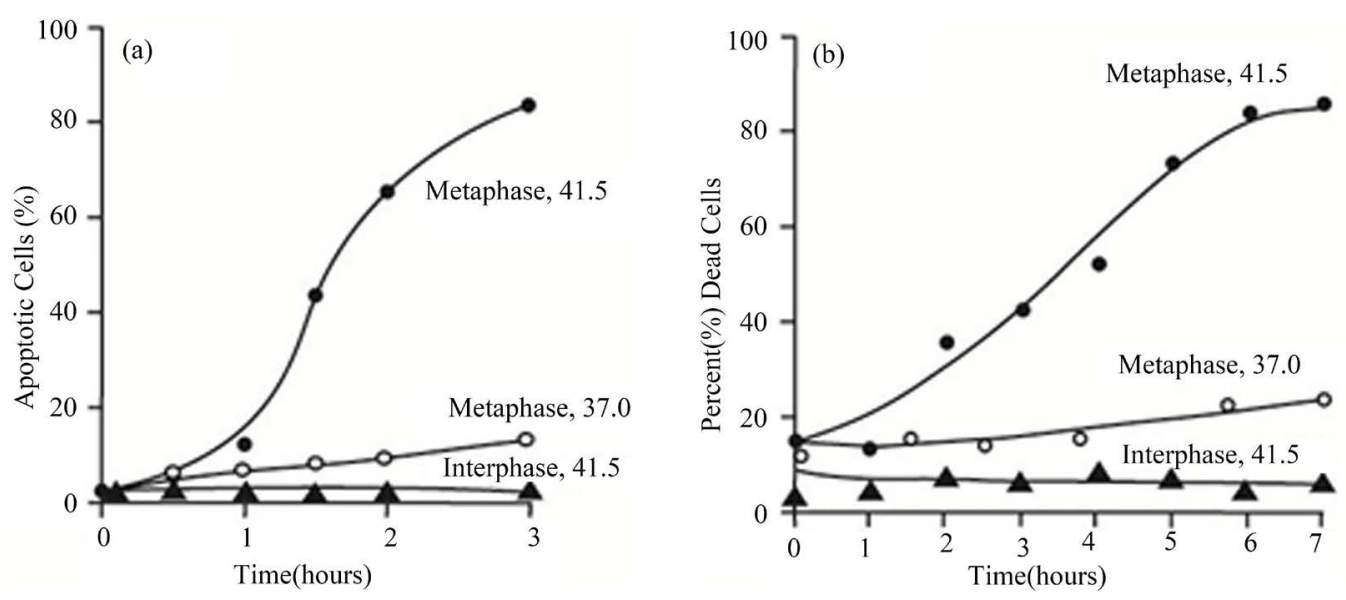

Figure 3. Heat treatment induces apoptosis in metaphase-arrested HeLa cells but has no detectable effect on interphase cells. (a) Cultures of metaphase-arrested cells (mitotic index 88\%) and unsynchronized cells (mitotic index 4\%) were prepared at $33.0^{\circ} \mathrm{C}$ and then either shifted to $41.5^{\circ} \mathrm{C}$ or left at $37.0^{\circ} \mathrm{C}$. The time courses show the percentage of cells displaying morphological changes characteristic of apoptosis (cf., Figure 1(b)) in the unsynchronized (predominantly interphase) culture at $41.5^{\circ} \mathrm{C}(\boldsymbol{\Delta}-\boldsymbol{\Delta})$, in the metaphase-arrested culture at $37.0^{\circ} \mathrm{C}(\circ-\circ)$, and in the metaphase-arrested culture at $41.5^{\circ} \mathrm{C}(\bullet-\bullet)$. Induction of apoptosis is not detected in the interphase cells. (b) Time course of cell death during heat treatment assayed by permeability to propidium iodide. Metaphase-arrested and interphase cultures growing at $37.0^{\circ} \mathrm{C}$ were either shifted to $41.5^{\circ} \mathrm{C}$ or left at $37.0^{\circ} \mathrm{C}$. Data is shown for interphase cells treated at $41.5^{\circ} \mathrm{C}(\boldsymbol{\Delta}-\boldsymbol{\Delta})$, metaphase-arrested cells left at $37.0^{\circ} \mathrm{C}$ (०—०), and metaphase-arrested cells treated at $41.5^{\circ}(\bullet-\bullet)$.
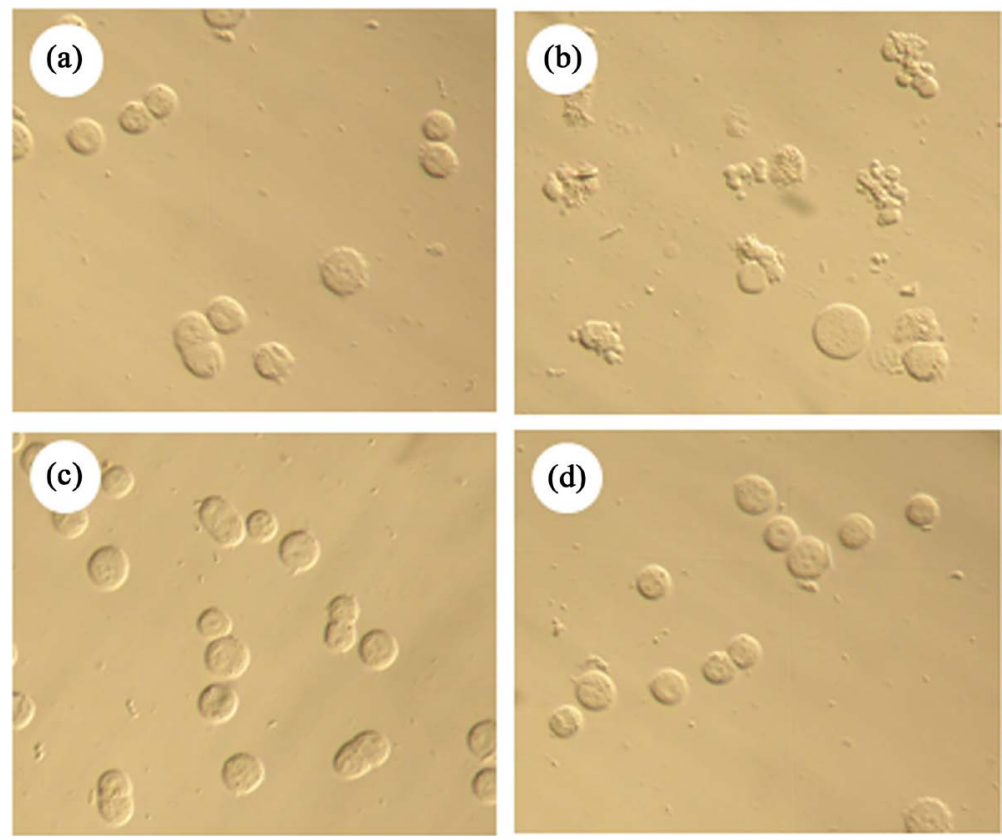

Figure 4. Changes in cell morphology viewed by Hoffman modulation contrast. (a) Metaphase-arrested cells; (b) Metaphase arrested cells treated 2 hrs at $41.5^{\circ} \mathrm{C}$; (c) Interphase cells; (d) Interphase cells treated $2 \mathrm{hrs}$ at $41.5^{\circ} \mathrm{C}$. 

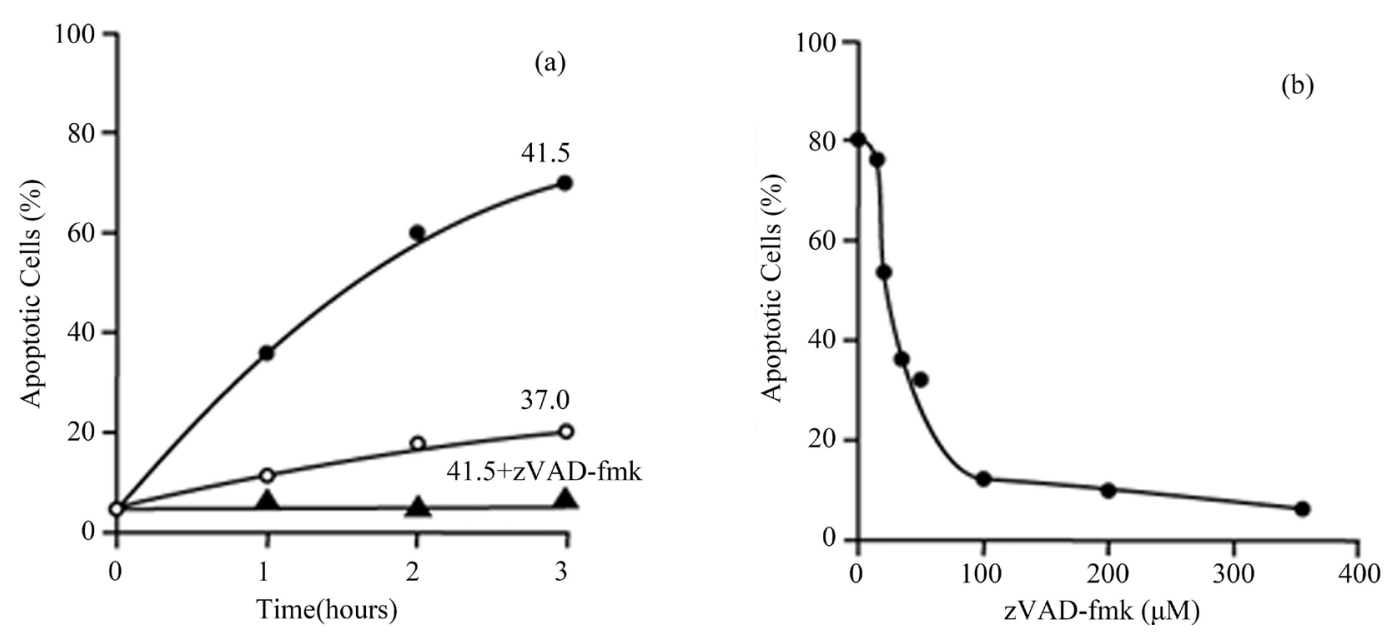

Figure 5. Morphological changes resulting from heat treatment of metaphase-arrested H-HeLa cells are blocked by the caspase inhibitor zVAD-fmk. Cells were arrested with nocodazole at $37.0^{\circ} \mathrm{C}$ (mitotic index $90 \%$ ) and then either left at $37.0^{\circ} \mathrm{C}$ or shifted to $41.5^{\circ} \mathrm{C}$, in the latter case either with or without zVAD-fmk. (a) Time course of apoptosis for cells shifted to $41.5^{\circ} \mathrm{C}(\bullet-)$, left at $37^{\circ} \mathrm{C}(\mathrm{\circ}-\mathrm{\circ})$, or shifted to $41.5^{\circ} \mathrm{C}$ in the presence of $350 \mu \mathrm{M} \mathrm{zVAD}$-fmk $(\boldsymbol{\Delta}-\mathbf{\Delta})$. (b) Extent of apoptosis after 3 hours at $41.5^{\circ} \mathrm{C}$ as a function of the zVAD-fmk concentration.

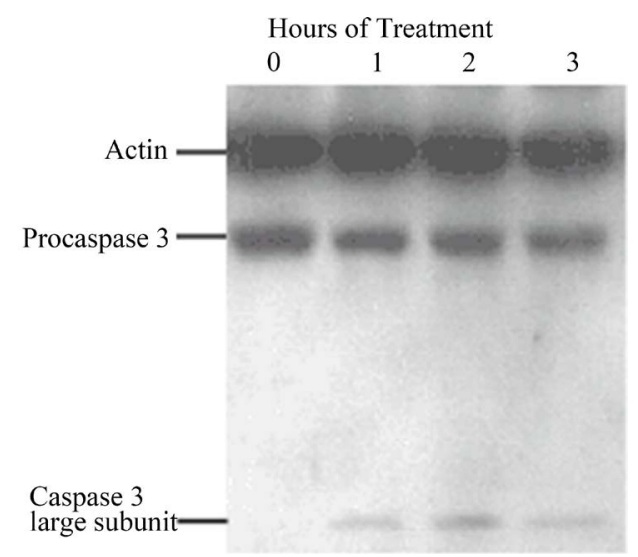

Figure 6. Cleavage of Procaspase 3 during heat treatment of metaphase-arrested HeLa cells. After 0, 1, 2 or 3 hours of heat treatment at $41.0^{\circ} \mathrm{C}$, metaphase-arrested cells (mitotic index $85 \%$ ) were lysed, sonicated, and prepared for SDS- polyacrylamide gel electrophoresis and western immunoblotting. The filter was stained first with an anti-Caspase 3 antibody and subsequently with an anti-actin antibody as a loading control.

To further verify the occurrence of apoptosis, cell extracts from metaphase-arrested HeLa cells were prepared after $0,1,2$ and 3 hours of treatment at $41.4^{\circ} \mathrm{C}$, separated by SDS polyacrylamide gel electrophoresis and analysed by western immunoblotting using anti-Caspase 3 antibodies. Figure 6 shows that the active Caspase 3 large subunit appears after heat treatment while the Procaspase 3 band becomes less intense. Appearance of cleaved and active Caspase 3 is a distinctive sign of apoptosis.

Caspase activation can also be observed in vivo using the fluorescein-labelled caspase inhibitor FAM-VADfmk. Figure 7(a) and Figure 7(c) show phase contrast micrographs of heat-treated $\left(41.5^{\circ} \mathrm{C}, 3 \mathrm{hrs}\right)$ and control metaphase-arrested cells, respectively. Figure 7(b) and Figure 7(d) show the same fields of cells, stained with FAM-VAD-fmk. Stained cells are seen in the heat-treated sample but not in the control. Table 1 shows that the percentage of cells labeled with the reagent parallels the percentage identified as apoptotic on the basis of morphology. However, in several repetitions of this experiment, the number of cells that stained with FAM-VADfmk was consistently lower than the number that appeared apoptotic on the basis of morphology (Table 1). The reason for this is not known, but one possible explanation is that some cells no longer stain with FAM-VADfmk because they have become permeable (cf. Figure 3(b)) and the caspases have diffused out. Alternatively, the caspases themselves may be proteolytically destroyed during the late stages of apoptosis. 

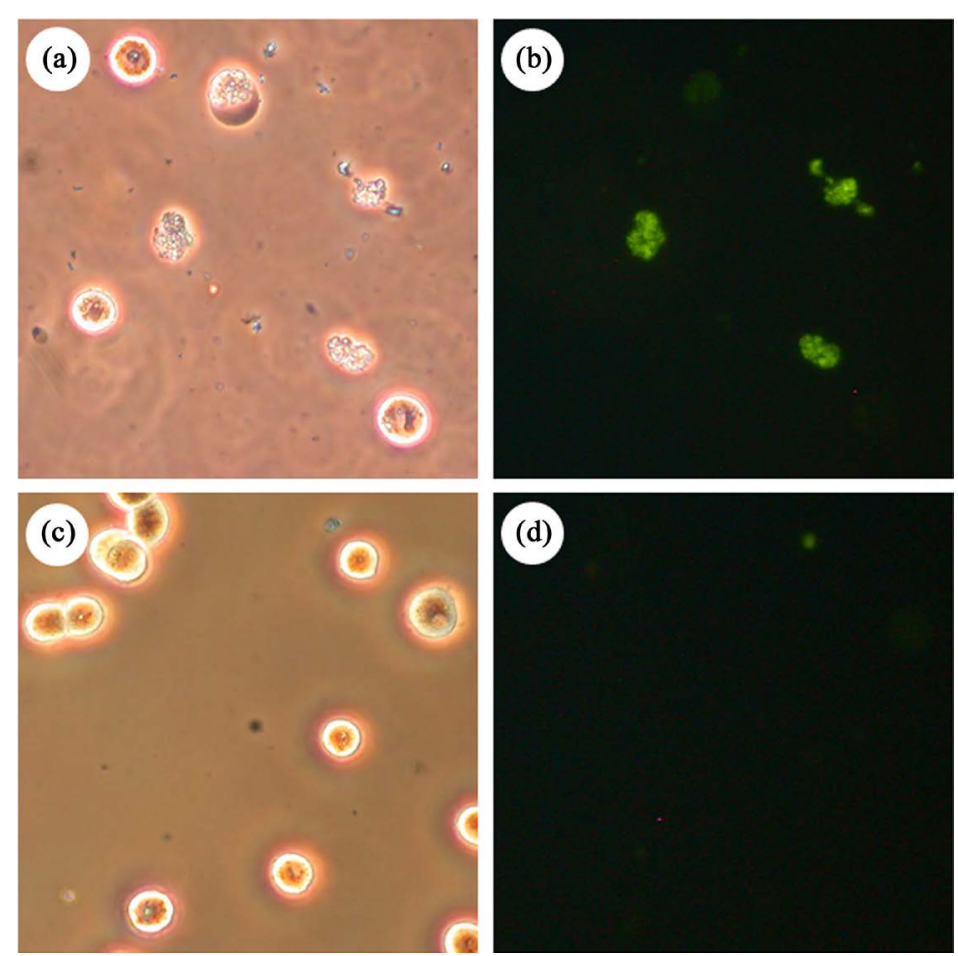

Figure 7. Detection of activated caspases in metaphase-arrested H-HeLa cells using FAM-VADfmk. (a)-(b) Cells treated 2.5 $\mathrm{hr}$ at $41.5^{\circ} \mathrm{C}$. (c)-(d) Control, not heat treated. (a) and (c), phase contrast; (b) and (d), FAM-VADfmk fluorescence.

Table 1. Staining of apoptotic cells with FAM-VAD-fmk.

\begin{tabular}{ccc}
\hline & $\begin{array}{c}\text { Apoptotic cells (\%) } \\
\text { (morphological changes viewed by Hoechst stain) }\end{array}$ & $\begin{array}{c}\text { Apoptotic cells (\%) } \\
\text { (FAM-VAD-fmk stain) }\end{array}$ \\
\hline Heat-treated, $41.5^{\circ} \mathrm{C}, 2.5 \mathrm{hr}$ & 50.3 & 37.6 \\
Control, $37.0^{\circ} \mathrm{C}, 2.5 \mathrm{hr}$ & 7.9 & 5.1 \\
\hline
\end{tabular}

\subsection{Further Characterization of the Phenomenon}

As previously noted, apoptosis is induced more rapidly at higher temperatures (Figure 2(b)). This raises the question: which is more important in determining the rate, the final temperature or the magnitude of the temperature shift? To answer this, a portion of a culture arrested in metaphase at $34^{\circ} \mathrm{C}$ and another portion arrested at $37^{\circ} \mathrm{C}$ were simultaneously shifted to $41.0^{\circ} \mathrm{C}$. As seen in Figure 8, the time courses for the two samples are virtually identical. We conclude that the rate of induction of apoptosis depends only on the final incubation temperature, not on the size of the temperature shift.

In all experiments described so far, cells were arrested in metaphase with nocodazole. In order to test whether the observed induction of apoptosis is peculiar to nocodazole-arrest, the effects of heat treatment on nocodazoleand paclitaxel-arrested cultures were compared (Figure 9(a)). Although paclitaxel-arrested cells show a higher background of apoptosis without heat treatment, it is clear that heat treatment induces apoptosis to a similar extent no matter which spindle poison is used to arrest the cells.

To test whether the rate of induction of apoptosis by hyperthermia depends on the length of time that the cells have been in metaphase-arrest, HeLa cells were grown in monolayers at $37.0^{\circ} \mathrm{C}$ and metaphase-arrested cells were prepared by a shake-off technique after treatment with nocodazole for only two hours. When an aliquot of these metaphase-arrested cells was immediately shifted to $41.5^{\circ} \mathrm{C}$, little or no increase in the number of apoptotic cells was seen during the first hour of heat treatment (Figure 9(b)). However, in an aliquot of the same metaphase-arrested culture that had been incubated for an additional 4 hrs at $37.0^{\circ} \mathrm{C}$ before being shifted to $41.5^{\circ} \mathrm{C}$, $28 \%$ of the cells underwent apoptosis during the first hour of heat treatment. This suggests that susceptibility to hyperthermia-induced apoptosis is not simply a matter of being in the metaphase-arrested state, but is at least in 
part a function of the length of time that a cell has been arrested.

In separate sets of experiments, we have observed less apoptosis with heat-treatment of metaphase-arrested HeLa $\mathrm{S}_{3}$ and HeLa-MKF than with H-HeLa cells. At first we suspected that this might be due to the use of different media, since the $S_{3}$ and MKF cells had been grown with $10 \%$ fetal calf serum while the H-HeLa were grown with $5 \%$ newborn calf serum. This is not the case, however. The differences among HeLa strains persist even when all are grown under the same conditions. However, for a given strain the extent of apoptosis is indeed affected by the type and concentration of serum, as shown in Figure 10. For H-HeLa, significantly less apoptosis is seen with fetal calf serum than with newborn calf serum when both are present at the same concentration, and with either type of serum less apoptosis is observed at higher serum concentrations.
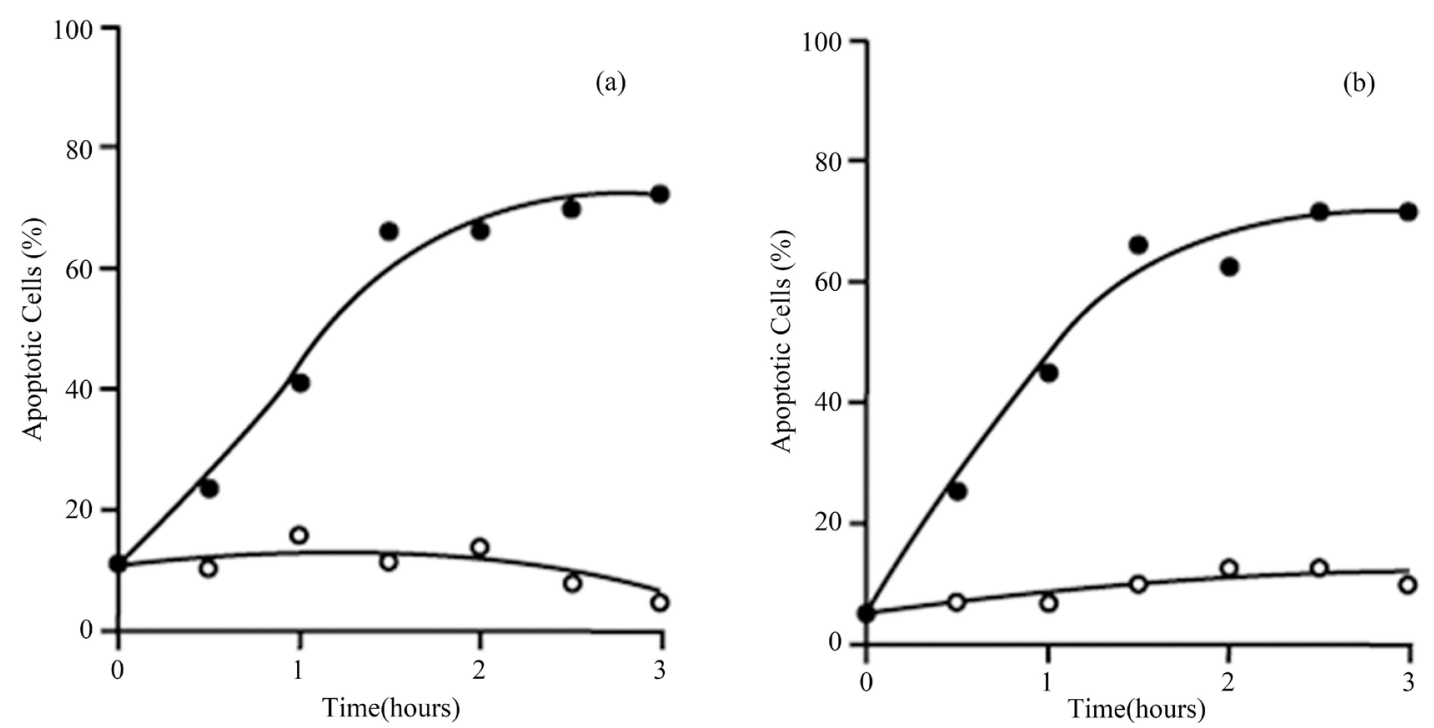

Figure 8. The extent of induction of apoptosis depends on the final temperature, not on the magnitude of the temperature shift. HeLa cultures were arrested in metaphase with nocodazole either at (a) $34.0^{\circ} \mathrm{C}$ (mitotic index $84 \%$ ) or (b) $37.0^{\circ} \mathrm{C} \mathrm{(mi-}$ totic index 85\%). One portion of each was left at the initial temperature (०-०) while another portion was shifted to $41.0^{\circ} \mathrm{C}$ $(\bullet-\bullet)$. The graphs show the percentage of apoptotic cells as a function of time.
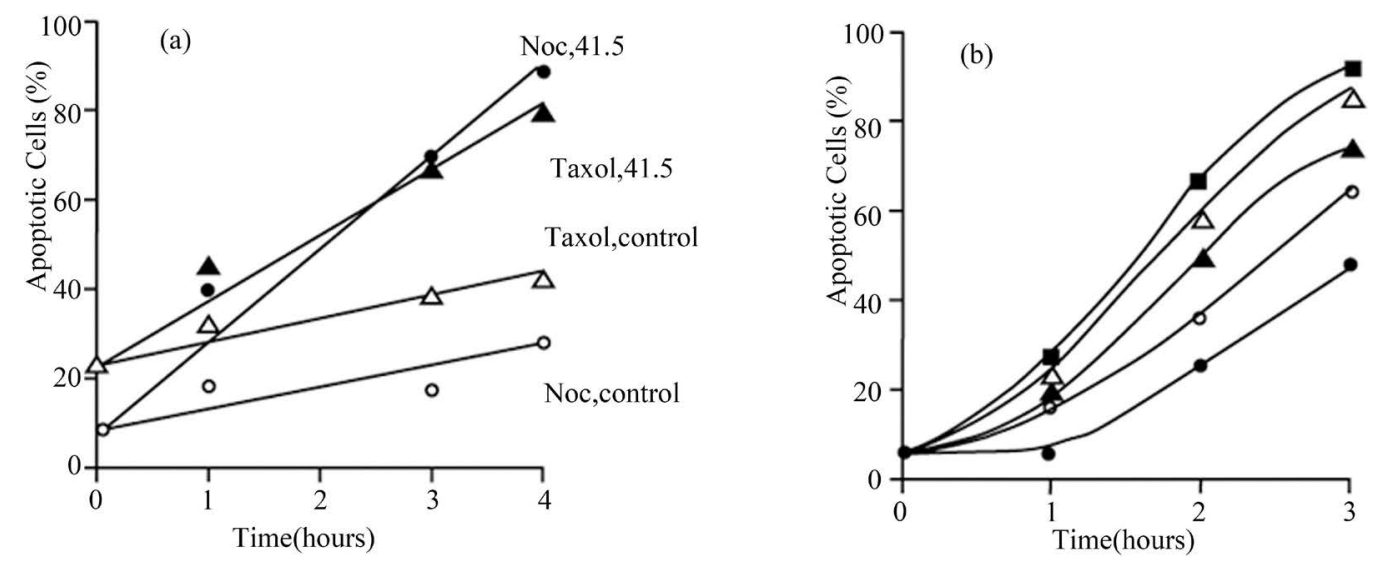

Figure 9. (a) Heat treatment induces apoptosis similarly in nocodazole- and paclitaxel-arrested H-HeLa cell cultures. Cultures were arrested in metaphase and portions were either incubated further at $37.0^{\circ} \mathrm{C}$ (control) or shifted to $41.5^{\circ} \mathrm{C}$ : Cells arrested with nocodazole and left at $37.0^{\circ} \mathrm{C}\left(\circ-\circ\right.$; Noc, control); nocodazole-arrested cells treated at $41.5^{\circ} \mathrm{C}(\bullet-\bullet$; Noc, 41.5$)$; Cells arrested with paclitaxel (Taxol) and left at $37.0^{\circ} \mathrm{C}\left(\Delta-\Delta\right.$; Taxol, control); paclitaxel-arrested cells treated at $41.5^{\circ} \mathrm{C}$ ( $\boldsymbol{\Delta}-\boldsymbol{\Delta}$; Taxol, 41.5). (b) The rate of induction of apoptosis depends on the length of time that the cells have been arrested in metaphase. Monolayer cultures growing at $37.0^{\circ} \mathrm{C}$ were treated with nocodazole for 2 hours and metaphase-arrested cells harvested by shake-off. Aliquots of these cells were either shifted to $41.5^{\circ} \mathrm{C}$ immediately $(\bullet-\bullet)$ or kept at $37.0^{\circ} \mathrm{C}$ and then shifted to $41.5^{\circ} \mathrm{C}$ after $1(\circ-\circ), 2(\boldsymbol{\Delta}-\boldsymbol{\Delta}), 3(\Delta-\Delta)$, or $4 \mathrm{hrs}(\boldsymbol{\square}-\mathbf{\square})$. The percentage of apoptotic cells is shown as a function of the time of treatment at $41.5^{\circ} \mathrm{C}$. 


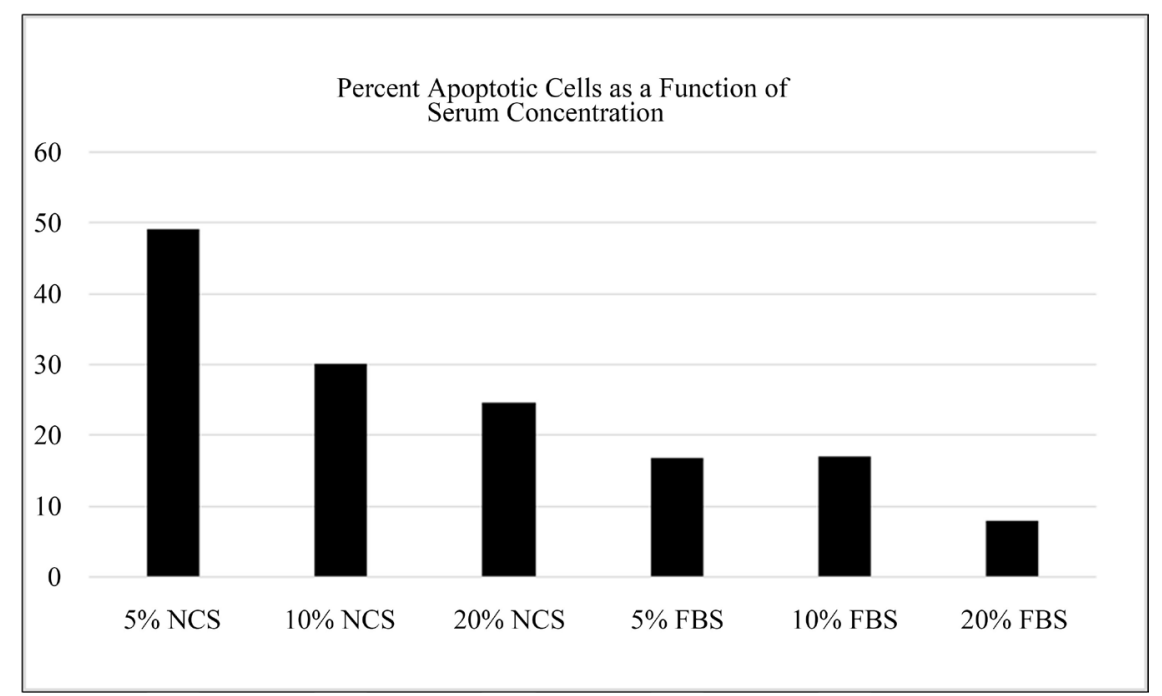

Figure 10. The rate of induction of apoptosis is affected by the type and concentration of serum in the medium. Monolayer cultures of H-HeLa cells were grown for at least $24 \mathrm{hr}$ in medium containing either newborn calf serum (NCS) or fetal calf (bovine) serum (FBS) at a concentration of either 5\%, 10\% or $20 \%$. After exposure to nocodazole for 16 hr, metaphase-arrested cells were obtained by a gentle shake-off technique and then treated at $41.5^{\circ} \mathrm{C}$.

\section{Discussion}

The results presented in this paper show that mild hyperthermia induces apoptosis in metaphase-arrested $\mathrm{H}-\mathrm{HeL}$ a cells but not in interphase cells. To our knowledge, this phenomenon has not been previously reported for any cultured cells. When H-HeLa cells are arrested in metaphase at $37^{\circ} \mathrm{C}$ and then shifted to higher temperature $\left(39^{\circ} \mathrm{C}-41.5^{\circ} \mathrm{C}\right)$, cell death occurs within a few hours (Figures 1-3), and several observations indicate that this is due to apoptosis. First, fluorescence microscopy and Hoffman modulation contrast microscopy show morphological changes characteristic of apoptosis, including blebbing of the plasma membrane and condensation and fragmentation of the nuclear material (Figure 1 and Figure 4); second, the morphological changes are completely blocked when the caspase inhibitor zVAD-fmk [3] [27] [28] is present during the heat treatment (Figure 5); third, western immunoblotting using an antibody to Caspase 3 reveals proteolytic cleavage of Procaspase 3 and appearance of the active Caspase 3 large subunit (Figure 6); and fourth, caspase activation can be visualized in vivo using the fluorescein-labeled caspase inhibitor, FAM-VAD-fmk (Table 1 and Figure 7).

This heat treatment induces apoptosis only in metaphase-arrested H-HeLa cells, not in interphase cells. When a nocodazole-arrested culture (predominantly but not entirely metaphase) is subjected to heat treatment, the number of metaphase cells decreases and the number of apoptotic cells increases correspondingly, but the number of interphase cells does not change significantly (Figure 2(a)). When an unsynchronized culture (predominantly interphase) is similarly heat-treated, little or no cell death is observed (Figure 3). A study of Jurkat T cells has also reported that apoptosis is more easily induced during nocodazole-arrest than during interphase [29].

Further experiments show that the induction of apoptosis in metaphase-arrested cells is more rapid at higher temperatures (Figure 2(b)), and that the critical factor in determining the rate is the final temperature, not the magnitude of the temperature shift (Figure 8). Also, the specific metaphase-arrest agent used is not important, since similar results are obtained with either nocodazole or paclitaxel (Figure 9(a)).

We have begun to examine the effects of heat treatment on metaphase-arrested cells of other cell lines. Surprisingly, much less apoptosis occurs with HeLa $\mathrm{S}_{3}$ and HeLa MKF than with H-HeLa (J.R. Paulson, A.K. Kresch and P.W. Mesner, unpublished work). In some cases (e.g., mouse FT210, Balb-3T3 and L929 cells), heat treatment simply causes the cells to exit mitosis and go back to interphase without chromosome segregation or cytokinesis. These cells presumably fail to undergo apoptosis because they return to interphase before the metaphase-specific mechanism that will lead to apoptosis has a chance to be initiated. With FT210 cells, which carry a temperature-sensitive mutation in the Cdk1 kinase [30], exit from mitosis is due to heat-inactivation of Cdk1/cyclin B [19]. For Balb-3T3 and L929 cells, it is not known why heat treatment causes a return to inter- 
phase, but it most likely also involves inactivation of Cdk1/cyclin B since that is a prerequisite for mitotic exit [31]-[33]. Interestingly, heat treatment of paclitaxel-arrested cells has been shown to induce apoptosis more efficiently when exit from mitosis is blocked by inhibiting the Anaphase-Promoting Complex (APC/C) [34].

Why does mild heat treatment induce apoptosis in metaphase-arrested H-HeLa? It might be a fortuitous effect peculiar to this cell line, but it is also conceivable that a specific mechanism has evolved. Having a low threshold for induction of apoptosis when cells suffer stress during mitosis may be advantageous to the organism. The most striking fact is that metaphase-arrested cells undergo apoptosis but interphase cells do not, so it makes sense to consider which structural and biochemical differences in mitotic cells might facilitate the induction of apoptosis. For example, decreased RNA and protein synthesis at mitosis [35]-[38] may hinder the cell's ability to mount a heat shock response. Lack of a nuclear envelope during mitosis may allow certain factors to reach the chromatin that would not do so during interphase.

Perhaps the first question to ask is whether the apoptosis we observe comes about by the intrinsic or the extrinsic pathway. Mitochondrial stress induces apoptosis via Caspase-9 and the intrinsic pathway whereas ER stress induces it via the extrinsic pathway. Apoptosis resulting from ER stress involves the unfolded protein response (UPR), Caspase-8 and Death Receptor 5 (DR5) [39]. The intrinsic and extrinsic pathways should be distinguishable using specific caspase inhibitors, but such experiments will need to be done with care since available caspase inhibitors are not completely specific [40].

At this point we can only speculate about the triggering mechanism. Possibilities include, but are not necessarily limited to, sequestration of the anti-apoptotic protein survivin, mitotic phosphorylation of certain proteins during mitosis, increased concentrations of ceramides, and/or decreased ATP levels. Note that these hypotheses are not mutually exclusive. More than one may be involved. Antagonists of survivin are known to induce apoptosis via the intrinsic pathway [41]. Having survivin tied up in the mitotic chromosome passenger complex [42] may also make the cells more sensitive to stress. Phosphorylation of the anti-apoptotic protein Bcl-2 and the pro-apoptotic protein Bim during mitosis is known to lower the threshold for induction of cell death [29] and phosphorylation of caspase-8 during mitosis can also predispose the cells to apoptosis [43]. Ceramides are key inducers or regulators of apoptosis [44]-[46] and they are known to accumulate to higher levels during mitosis [46]-[48]. Ceramide is involved in the induction of apoptosis by heat shock [49], and a combination of ceramide and paclitaxel has been shown to enhance apoptosis in cancer cells [50]. Depletion of ATP levels during mitosis reportedly also makes cells more susceptible to apoptosis [51].

Further work will be necessary to test these hypotheses and to elucidate the detailed mechanism, but understanding the process could have practical importance. Hyperthermia is widely used to treat tumors [52] [53] and spindle poisons are among the many drugs used in cancer chemotherapy that are thought to work by triggering apoptosis [7]-[10]. A combination of these two approaches could potentially be exploited to improve cancer treatments. Interestingly, it has been reported that the effectiveness of the spindle poison Combretastatin in treating solid tumors is enhanced by simultaneous treatment with hyperthermia [54] [55], although in these studies the drug treatment was probably too brief to arrest a significant proportion of the tumor cells in metaphase. If the relevant components and processes can be identified, it may be possible to mimic, in interphase cells, the changes that sensitize metaphase-arrested cells to hyperthermia. This could greatly increase the usefulness of hyperthermia in cancer treatment.

\section{Acknowledgements}

This work was supported by grants from the University of Wisconsin-Oshkosh Faculty and Undergraduate Student Collaborative Research Program, the University of Wisconsin-Oshkosh Faculty Development Board, and the University of Wisconsin-Whitewater Faculty Development Board. It was also aided by grants GM-39915 and GM-46040 from the National Institutes of Health, U.S. Public Health Service. Some of the results were previously presented at the $16^{\text {th }}$ National Conference on Undergraduate Research (NCUR).

\section{References}

[1] Green, D.R. (1998) Apoptotic Pathways: The Roads to Ruin. Cell, 94, 695-698. http://dx.doi.org/10.1016/S0092-8674(00)81728-6

[2] Song, Z. and Steller, H. (1999) Death by Design: Mechanism and Control of Apoptosis. Trends in Cell Biology, 9, M49-M52. http://dx.doi.org/10.1016/S0962-8924(99)01670-0 
[3] Nicholson, D.W. and Thornberry, N.A. (1997) Caspases: Killer Proteases. Trends in Biochemical Sciences, 22, 299306. http://dx.doi.org/10.1016/S0968-0004(97)01085-2

[4] Thornberry, N.A. and Lazebnik, Y. (1998) Caspases: Enemies within. Science, 281, 1312-1316. http://dx.doi.org/10.1126/science.281.5381.1312

[5] Earnshaw, W.C., Martins, L.M. and Kaufmann, S.H. (1999) Mammalian Caspases: Structure, Activation, Substrates and Functions during Apoptosis. Annual Review of Biochemistry, 68, 383-424. http://dx.doi.org/10.1146/annurev.biochem.68.1.383

[6] Enari, M., Sakahira, H., Yokoyama, H., Okawa, K., Iwamatsu, A. and Nagata, S. (1998) A Caspase-Activated DNase That Degrades DNA during Apoptosis, and Its Inhibitor ICAD. Nature, 391, 43-50. http://dx.doi.org/10.1038/34112

[7] Hickman, J.A. (1992) Apoptosis Induced by Anticancer Drugs. Cancer and Metastasis Reviews, 11, 121-139. http://dx.doi.org/10.1007/BF00048059

[8] Cotter, T.G., Glynn, J.M., Echeverri, F. and Green, D.R. (1992) Induction of Apoptosis by Chemotherapeutic Agents Occurs during All Phases of the Cell Cycle. Anticancer Research, 12, 773-780.

[9] Kaufmann, S.H. and Earnshaw, W.C. (2000) Induction of Apoptosis by Cancer Chemotherapy. Experimental Cell Research, 256, 42-49. http://dx.doi.org/10.1006/excr.2000.4838

[10] Reed, J.C. (2002) Apoptosis-Based Therapies. Nature Reviews Drug Discovery, 1, 111-121. http://dx.doi.org/10.1038/nrd726

[11] Pollard, T. and Earnshaw, W.C. (2003) Cell Biology. Saunders, Philadelphia.

[12] Harmon, B.V., Takano, Y.S., Winterford, C.M. and Gobe, G.C. (1991) The Role of Apoptosis in the Response of Cells and Tumours to Mild Hyperthermia. International Journal of Radiation Biology, 59, 489-501. http://dx.doi.org/10.1080/09553009114550441

[13] Ahmed, K., Tabuchi, Y. and Kondo, T. (2015) Hyperthermia: An Effective Strategy to Induce Apoptosis in Cancer Cells. Apoptosis, 20, 1411-1419. http://dx.doi.org/10.1007/s10495-015-1168-3

[14] Ahmed, K. and Zaidi, S.F. (2013) Treating Cancer with Heat: Hyperthermia as Promising Strategy to Enhance Apoptosis. Journal of Pakistan Medical Association, 63, 504-508.

[15] De Nardo, G.L. and De Nardo, S.J. (2008) Update: Turning the Heat on Cancer. Cancer Biotherapy and Radiopharmaceuticals, 23, 671-680. http://dx.doi.org/10.1089/cbr.2008.0591

[16] Hildebrandt, B. and Wust, P. (2007) The Biologic Rationale of Hyperthermia. Cancer Treatment and Research, 134, 171-184. http://dx.doi.org/10.1007/978-0-387-48993-3_10

[17] Verdoodt, B., Decordier, I., Geleyns, K., Cunha, M., Cundari, E. and Kirsch-Volders, M. (1999) Induction of Polyploidy and Apoptosis after Exposure to High Concentrations of the Spindle Poison Nocodazole. Mutagenesis, 14, 513520. http://dx.doi.org/10.1093/mutage/14.5.513

[18] Yamada, H.Y. and Gorbsky, G.J. (2006) Inhibition of TRIP1/S8/hSug1, a Component of the Human 19S Proteasome, Enhances Mitotic Apoptosis Induced by Spindle Poisons. Molecular Cancer Therapeutics, 5, 29-38. http://dx.doi.org/10.1158/1535-7163.MCT-05-0126

[19] Paulson, J.R. (2007) Inactivation of Cdk1/Cyclin B in Metaphase-Arrested Mouse FT210 Cells Induces Exit from Mitosis without Chromosome Segregation or Cytokinesis and Allows Passage through Another Cell Cycle. Chromosoma, 116, 215-225. http://dx.doi.org/10.1007/s00412-006-0093-1

[20] Medappa, K.C., McLean, C. and Rueckert, R.R. (1971) On the Structure of Rhinovirus 1A. Virology, 44, $259-270$. http://dx.doi.org/10.1016/0042-6822(71)90258-3

[21] Heinz, B.A., Rueckert, R.R., Shepard, D.A., Dutko, F.J., McKinlay, M.A., Fancher, M., Rossmann, M.G., Badger, J. and Smith, T.J. (1989) Genetic and Molecular Analyses of Spontaneous Mutants of Human Rhinovirus 14 That Are Resistant to an Antiviral Compound. Journal of Virology, 63, 2476-2485.

[22] Paulson, J.R., Ciesielski, W.A., Schram, B.R. and Mesner, P.W. (1994) Okadaic Acid Induces Dephosphorylation of Histone H1 in Metaphase-Arrested HeLa Cells. Journal of Cell Science, 107, 267-273.

[23] Paulson, J.R. (1982) Isolation of Mitotic Chromosome Clusters from Metaphase-Arrested HeLa Cells. Chromosoma, 85, 571-581. http://dx.doi.org/10.1007/BF00327351

[24] Paulson, J.R., Patzlaff, J.S. and Vallis, A.J. (1996) Evidence that the Endogenous Histone H1 Phosphatase in HeLa Mitotic Chromosomes Is Protein Phosphatase 1, Not Protein Phosphatase 2A. Journal of Cell Science, 109, 1437-1447.

[25] Patterson, M.K. (1979) Measurement of Growth and Viability of Cells in Culture. Methods in Enzymology, 58, 141152. http://dx.doi.org/10.1016/S0076-6879(79)58132-4

[26] Mesner, P.W., Bible, K.C., Martins, L.M., Kottke, T.J., Srinivasula, S.M., Svingen, P.A., Chilcote, T.J., Basi, G.S., Tung, J.S., Krajewski, S., Reed, J.C., Alnemri, E.S., Earnshaw, W.C. and Kaufmann, S.H. (1999) Characterization of 
Caspase Processing and Activation in HL-60 Cell Cytosol under Cell-Free Conditions: Nucleotide Requirement and Inhibitor Profile. The Journal of Biological Chemistry, 274, 22635-22645. http://dx.doi.org/10.1074/jbc.274.32.22635

[27] Zhu, H., Fearnhead, H.O. and Cohen, G.M. (1995) An ICE-Like Protease Is a Common Mediator of Apoptosis Induced by Diverse Stimuli in Human Monocytic THP.1 Cells. FEBS Letters, 374, 303-308. http://dx.doi.org/10.1016/0014-5793(95)01116-V

[28] Slee, E.A., Zhu, H., Chow, S.C., MacFarlane, M., Nicholson, D.W. and Cohen, G.M. (1996) Benzyloxycarbonyl-Val-Ala-Asp (OMe) Fluoromethylketone (Z-VAD.FMK) Inhibits Apoptosis by Blocking the Processing of CPP32. Biochemical Journal, 315, 21-24. http://dx.doi.org/10.1042/bj3150021

[29] Han, C.R., Jun, D.Y., Lee, J.Y. and Kim, Y.H. (2014) Prometaphase Arrest-Dependent Phosphorylation of Bcl-2 and Bim Reduces the Association of Bcl-2 with Bac or Bim, Provoking Bak Activation and Mitochondrial Apoptosis in Nocodazole-Arrested Jurkat T Cells. Apoptosis, 19, 224-240. http://dx.doi.org/10.1007/s10495-013-0928-1

[30] Th’ng, J.P., Wright, P.S., Hamaguchi, J., Lee, M.G., Norbury, C.J., Nurse, P. and Bradbury, E.M. (1990) The FT210 Cell Line Is a Mouse G2 Phase Mutant with a Temperature-Sensitive CDC2 Gene Product. Cell, 63, 313-324. http://dx.doi.org/10.1016/0092-8674(90)90164-A

[31] Murray, A.W., Solomon, M.J. and Kirschner, M.W. (1989) The Role of Cyclin Synthesis and Degradation in the Control of Maturation Promoting Factor Activity. Nature, 339, 280-286. http://dx.doi.org/10.1038/339280a0

[32] Rimmington, G., Dalby, B. and Glover, D.M. (1994) Expression of N-Terminally Truncated Cyclin B in the Drosophila Larval Brain Leads to Mitotic Delay at Late Anaphase. Journal of Cell Science, 107, 2729-2738.

[33] Luo, Q., Michaelis, C. and Weeks, G. (1994) Overexpression of a Truncated Cyclin B Gene Arrests Dictyostelium Cell Division during Mitosis. Journal of Cell Science, 107, 3105-3114.

[34] Giovinazzi, S., Bellapu, D., Morozov, V.M. and Ishov, A.M. (2013) Targeting Mitotic Exit with Hyperthermia or APC/C Inhibition to Increase Paclitaxel Efficacy. Cell Cycle, 12, 2598-2607. http://dx.doi.org/10.4161/cc.25591

[35] Baserga, R. (1962) A Study of Nucleic Acid Synthesis in Ascites Tumor Cells by Two-Emulsion Autoradiography. The Journal of Cell Biology, 12, 633-637. http://dx.doi.org/10.1083/jcb.12.3.633

[36] Prescott, D.M. and Bender, M.A. (1962) Synthesis of RNA and Protein during Mitosis in Mammalian Tissue Culture Cells. Experimental Cell Research, 26, 260-268. http://dx.doi.org/10.1016/0014-4827(62)90176-3

[37] Konrad, C.G. (1963) Protein Synthesis and RNA Synthesis during Mitosis in Animal Cells. The Journal of Cell Biology, 19, 267-277. http://dx.doi.org/10.1083/jcb.19.2.267

[38] Leresche, A., Wolf, V.J. and Gottesfeld, J.M. (1996) Repression of RNA Polymerase II and III Transcription during M Phase of the Cell Cycle. Experimental Cell Research, 229, 282-288. http://dx.doi.org/10.1006/excr.1996.0373

[39] Lu, M., Lawrence, D.A., Marsters, S., Acosta-Alvear, D., Kimmig, P., Mendez, A.S., Paton, A.W., Paton, J.C., Walter, P. and Ashkenazi, A. (2014) Opposing Unfolded-Protein-Response Signals Converge on Death Receptor 5 to Control Apoptosis. Science, 345, 98-101. http://dx.doi.org/10.1126/science.1254312

[40] Berger, A.B., Sexton, K.B. and Bogyo, M. (2006) Commonly Used Caspase Inhibitors Designed Based on Substrate Specificity Profiles Lack Selectivity. Cell Research, 16, 961-963. http://dx.doi.org/10.1038/sj.cr.7310112

[41] Blanc-Brude, O.P., Mesri, M., Wall, N.R., Plescia, J., Dohi, T. and Altieri, D.C. (2003) Therapeutic Targeting of the Survivin Pathway in Cancer: Initiation of Mitochondrial Apoptosis and Suppression of Tumor-Associated Angiogenesis. Clinical Cancer Research, 9, 2683-2692.

[42] Jeyaprakash, A.A., Klein, U.R., Lindner, D., Ebert, J., Nigg, E.A. and Conti, E. (2007) Structure of a Survivin-Borealin-INCENP Core Complex Reveals how Chromosomal Passengers Travel Together. Cell, 131, 271-285. http://dx.doi.org/10.1016/j.cell.2007.07.045

[43] Matthess, Y., Raab, M., Knecht, R., Becker, S. and Strebhardt, K. (2014) Sequential Cdk1 and Plk1 Phosphorylation of Caspase-8 Triggers Apoptotic Cell Death during Mitosis. Molecular Oncology 8, 596-608. http://dx.doi.org/10.1016/j.molonc.2013.12.013

[44] Pettus, B.J., Chalfant, C.E. and Hannun, Y.A. (2002) Ceramide in Apoptosis: An Overview and Current Perspectives. Biochimica et Biophysica Acta (BBA), 1585, 114-125. http://dx.doi.org/10.1016/S1388-1981(02)00331-1

[45] Bieberich, E., MacKinnon, S., Silva, J., Noggle, S. and Condie, B.G. (2003) Regulation of Cell Death in Mitotic Neural Progenitor Cells by Asymmetric Distribution of Prostate Apoptosis Response 4 (PAR-4) and Simultaneous Elevation of Endogenous Ceramide. The Journal of Cell Biology, 162, 469-479. http://dx.doi.org/10.1083/jcb.200212067

[46] Cuvillier, O., Pirianov, G., Kleuser, B., Vanek, P.G., Coso, O.A., Gutkind, S. and Spiegel, S. (1996) Suppression of Ceramide-Mediated Programmed Cell Death by Sphingosine-1-Phosphate. Nature, 381, 800-803. http://dx.doi.org/10.1038/381800a0

[47] Yokoyama, K., Suzuki, M., Kawashima, I., Karasawa, K., Nojima, S., Enomoto, T., Tai, T., Suzuki, A. and Setaka, M. (1997) Changes in Composition of Newly Synthesized Sphingolipids of HeLa Cells during the Cell Cycle: Suppression 
of Sphingomyelin and Higher-Glycosphingolipid Synthesis and Accumulation of Ceramide and Glucosylceramide in Mitotic Cells. European Journal of Biochemistry, 249, 450-455. http://dx.doi.org/10.1111/j.1432-1033.1997.00450.x

[48] Lee, J.Y., Leonhardt, L.G. and Obeid, L.M. (1998) Cell-Cycle-Dependent Changes in Ceramide Levels Preceding Retinoblastoma Protein Dephosphorylation in G2/M. Biochemical Journal, 334, 457-461. http://dx.doi.org/10.1042/bj3340457

[49] Kondo, T., Matsuda, T., Kitano, T., Takahashi, A., Tashima, M., Ishikura, H., Umehara, H., Domae, N., Uchiyama, T. and Okazaki, T. (2000) Role of c-jun Expression Increased by Heat Shock- and Ceramide-Activated Caspase-3 in HL60 Cell Apoptosis. The Journal of Biological Chemistry, 275, 7668-7676. http://dx.doi.org/10.1074/jbc.275.11.7668

[50] Mehta, S., Blackinton, D., Omar, I., Kouttab, N., Myrick, D., Klostergaard, J. and Wanebo, H. (2000) Combined Cytotoxic Action of Paclitaxel and Ceramide against the Human Tu138 Head and Neck Squamous Carcinoma Cell Line. Cancer Chemotherapy and Pharmacology, 46, 85-92. http://dx.doi.org/10.1007/s002800000140

[51] Miyazaki, N., Kurihara, K., Nakano, H. and Shinohara, K. (2002) Role of ATP in the Sensitivity to Heat and the Induction of Apoptosis in Mammalian Cells. International Journal of Hyperthermia, 18, 316-331.

[52] Falk, M.H. and Issels, R.D. (2001) Hyperthermia in Oncology. International Journal of Hyperthermia, 17, 1-18.

[53] Alexander, H.R. (2003) Hyperthermia and Its Modern Use in Cancer Treatment. Cancer, 98, 219-221. http://dx.doi.org/10.1002/cncr.11471

[54] Eikesdal, H.P., Bjerkvig, R., Raleigh, J.A., Mella, O. and Dahl, O. (2001) Tumor Vasculature Is Targeted by the Combination of Combretastatin A-4 and Hyperthermia. Radiotherapy and Oncology, 61, 313-320. http://dx.doi.org/10.1016/S0167-8140(01)00450-9

[55] Murata, R., Overgaard, J. and Horsman, M.R. (2001) Combretastatin A-4 Disodium Phosphate: A Vascular Targeting Agent That Improves the Anti-Tumor Effects of Hyperthermia, Radiation and Mild Thermoradiotherapy. International Journal of Radiation Oncology Biology Physics, 51, 1018-1024. http://dx.doi.org/10.1016/S0360-3016(01)01742-4

\section{Submit or recommend next manuscript to SCIRP and we will provide best service for you:}

Accepting pre-submission inquiries through Email, Facebook, Linkedin, Twitter, etc A wide selection of journals (inclusive of 9 subjects, more than 200 journals)

Providing a 24-hour high-quality service

User-friendly online submission system

Fair and swift peer-review system

Efficient typesetting and proofreading procedure

Display of the result of downloads and visits, as well as the number of cited articles

Maximum dissemination of your research work

Submit your manuscript at: http://papersubmission.scirp.org/ 